\title{
The impact of organizational culture on innovation for the development of tourism SMEs in the municipality of Caborca, Sonora
}

\section{El impacto de la Cultura Organizacional en la innovación para el desarrollo de las SMEs turísticas en el Municipio de Caborca, Sonora}

\author{
SAUCEDO-MONARQUE, Javiert’, HERNÁNDEZ-PONCE, Oscar Ernesto*, VALDEZ-JUÁREZ, \\ Luis Enrique
}

Instituto Tecnológico de Sonora.

ID $1^{\text {st }}$ Author: Javier, Saucedo-Monarque / ORC ID: 0000-0002-8111-3909, Researcher ID Thomson: T-7019-2018, CVU CONACYT ID: 287325

ID $1^{\text {st }}$ Coauthor: Oscar Ernesto, Hernández-Ponce / ORC ID: 000-0001-7169-8854, Researcher ID Thomson: X-22192018, CVU CONACYT ID: 284745

ID $2^{\text {nd }}$ Coauthor: Luis Enrique, Valdez-Juárez / ORC ID: 0000-0002-3754-4349, Researcher ID Thomson: N-97722019, CVU CONACYT ID: 845468

DOI: $10.35429 / J B S .2019 .16 .5 .1 .11$

Received March 12, 2019; Accepted June 10, 2019

\begin{abstract}
The results presented in this study related the factor of organizational culture with innovation for the development of small tourist businesses (SMEs) in the municipality of Caborca, Sonora. For which an exploratory analysis of the model, was made to subsequently analyze the Association of variables through the model of the Chi-square and thus be able to check the predictive and explanatory power of the same by means of Probit and Logit analysis. The collection of data was used as measurement instrument a structured questionnaire was administered to managers or entrepreneurs of tourism SMEs in the municipality of Caborca, Sonora. Where was the reliability of the instrument for measuring, the $\mathrm{R}^{2}$ and significance of the model Chi square statistical analysis was used to identify the relationship and association between the variables of the proposed model, obtaining the coefficient Gamma with a strong correlation between the variables, as well as Gamma, Probit and Logit values, acceptable values for the relationship between the dependent variable and the independent variable was observed. A higher rate and robustness of prediction of the variables with acceptable significance was also obtained.
\end{abstract}

Development, Innovation, Organizational culture, Small tourism businesses and Tourism

\begin{abstract}
Resumen
Los resultados presentados en esta investigación relacionan el factor de la cultura organizacional con la innovación para el desarrollo de las pequeñas empresas turísticas (SMEs) en el Municipio de Caborca, Sonora. Para lo cual se realizó un análisis exploratorio del modelo, para posteriormente analizar la asociación de las variables a través del modelo de la ji cuadrada y así poder comprobar el poder predictivo y explicativo de las mismas por medio del análisis Probit y Logit. En la recolección de los datos se empleó como instrumento de medición un cuestionario estructurado que se administró a los gerentes y/o empresarios de las SMEs turísticas en el Municipio de Caborca, Sonora. Dónde se obtuvo la confiabilidad del instrumento de medición, la $\mathrm{R}^{2} \mathrm{y}$ significancia del modelo. Para identificar la relación y asociación entre las variables del modelo propuesto, se utilizó la Ji cuadrada para su análisis estadístico, obteniéndose el coeficiente Gamma con una fuerte correlación entre las variables, además de los valores Gamma, Probit y Logit, se observó valores aceptables de la relación entre la variable dependiente y la variable independiente. También se obtuvo un mayor porcentaje y robustez de predicción de las variables con un nivel de significancia aceptable.
\end{abstract}

Cultura Organizacional, Desarrollo, Innovación, SMEs turísticas y Turismo

Citation: SAUCEDO-MONARQUE, Javier, HERNÁNDEZ-PONCE, Oscar Ernesto, VALDEZ-JUÁREZ, Luis Enrique. The impact of organizational culture on innovation for the development of tourism SMEs in the municipality of Caborca, Sonora. Journal of Bussines and SMEs. 2019. 5-16: 1-11

$\dagger$ Researcher contributing first author. 


\section{Introduction}

Tourism companies such as lodging, food and beverage services, transportation, entertainment, tourist information, recreational activities, tourist guides, among others, are part of the structure of the tourism system, which, complemented by tourism infrastructure and superstructure, make up the complementary offer of any tourist destination, which serve to develop any tourist product composed of all natural and cultural tourist attractions, called the primary offer or tourist heritage and the complementary offer. Based on the above, it can be affirmed that the essence of tourism activity is the tourist service offered by tourism services companies; dedicated to meet the needs of tourists that make up the demand for this service. Demand that is generated by the attraction of the various products offered by a tourist destination and that depends on them whether the tourist product is competitive or not.

In this sense, innovation is a determining element to achieve competitiveness that supports the sustainable tourism development of a region. In other words, innovation is the way in which entrepreneurs can cope with change, generating opportunities in their businesses. In addition to providing resources that are capable of generating value, so innovation represents the creation of those resources, so Peter Drucker (1985) mentions that resources exist until man gives economic value to something natural. Innovation is a factor that can determine the long-term competitive advantage of any company, since the constant changes in the internal and external environment of any organization, forces to seek innovation to be competitive. Innovation is also a central idea in the popular imagination, in the media and in public policy. In sum, innovation has become an emblem of modern society and the panacea to solve many problems (Godin, 2008).

Innovation is generally born from the incorporation of scientific knowledge produced from the results of research and development (R\&D) activities, whose successful application means a positive breakdown of the technological level prior to the time of innovation.
The capacity for innovation is linked to the education and training processes, playing an important role the capacity of $R \& D$, professional and labor learning, the ability to identify and acquire knowledge, the ability to adapt technology, forming in this way An innovative organizational culture. Albornoz (2009), mentions that the government, universities, public science and technology institutions, professional associations, private consultants, industrial research associations and technological services institutes constitute the mesh that supports, makes feasible and gives relevance to the process of innovation However, it does not change the fact that the basic phenomenon is innovation and that, therefore, the main actors are companies (strictly speaking, they are the "subjects" of the innovation process).

Small and medium-sized tourism companies (SMEs) are unaware of what the innovation management process consists of and this is reflected in an incipient development of new products and processes compared to other sectors (Gallouj and Sundbo, 1998; Hjalager, 2002 ; Volo, 2004). International organizations such as UNWTO (2002) or OECD (2006), have encouraged small businesses and destinations to incorporate innovation as their competitive strategy, they still do not understand the sources and patterns of innovative tourism activity, what is indispensable for the development of better policies for your support (Monfort and Camisón, 2009).

SMEs have distinguished themselves by lacking medium and long-term plans, resulting in limitations and difficulties in adopting an organizational culture as part of their strategy. The main limitations that the literature exhibits are: the lack of financial budget, lack of trained human resources, high turnover of staff, lack of motivation, knowledge is tacit, little interest of managers and infrastructure is obsolete (Lee and Lan, 2011; Mageswari, Sivasubramanian and Srikantha Dath, 2015). Organizational culture is understood as the set of beliefs and meanings that have been naturalized by members of the organization (thinking habits), which characterizes and makes one company innovative from another. Companies are formed from their daily interactions, where their interactions become institutional behaviors and these in turn become individual behaviors. 
The foregoing highlights that organizations and individuals are entities that form and transform each other (Munduate, 1997). Change and innovation are necessary and are the purpose of organizations. Since these must change their current stability and order, with processes of change, innovation, the implementation of coordination and control mechanisms, as well as the promotion of their autonomy and creativity (Weick, nineteen ninety five).

The organizational culture becomes the habits and values that order the behaviors and activities of a company (García, 2006). This variable helps us understand the way of thinking and behavior of the organization where multiple relationships converge, which allows us to know the sources of power and control exercised in their activities and that can influence for or against the innovation activities that companies tourist plans to implement.

The organization culture is a phenomenon that produces culture and is a social instrument that produces goods, services and byproducts as cultural artifacts. This is defined as a social glue that holds the organization together, expresses the values and beliefs shared by all the members of an organization and that are manifested through myths, legends, specialized language (Smircich, 1983).

In the intercultural communication model where it is established that the members of a nation are seen as bearers of a common culture that influences the behavior of organizations. Where members of the organization learn to create new forms of management and organization that goes beyond the cultures of its members (Adler, 1991, p. 108). The concept of culture has been taken from cognitive anthropology (Frake, 1983). Where the comparative, explicit and tacit cultural knowledge is sought, from which its social context is constructed.

For its part, Geertz (1973) describes culture detailing people, events and actions, as a product of history that itself is connected to a wider group of economic, social, political and cultural processes.
According to Schein (1985) the essence of culture is cognitive, rather than objective or symbolic. The values, norms, events and utensils are at an accessible level and can be considered as culture. Other researchers have used empirically derived categories (Sackmann, 1991) and others support the categories that result from a particular culture and are used in organizations (Kleinberg, 1989). Skarzynski, P. and Gibson, R. (2008), mention that in order to develop a strong capacity for innovation in the organization, a systematic effort is needed from everyone, from the support of the highest level executives, the existence of a structure of support, people motivated and trained in innovation techniques, the development of monitoring and orientation processes and tools, and the strengthening of a culture and values aligned with innovation are fundamental to success.

The degree of innovation of organizations depends on exogenous variables such as the relationship of companies in the field (Lugones, G., Peirano, F., Giudicatti, M. and Raffo, J., 2003) number of commercial alliances (Freeman, 1991; Hage and Alter, 1997; Lechner, C., Dowling, M. and Welpe, I., 2006).) The link with research institutions (DeBresson and Amesse, 1991; Freeman, 1991; Hage and Alter, 1997; Lechner et al., 2006) with whom he shares knowledge (Lugones et al.,2003; González and Gálvez, 2008).

The innovations in the organizations imply new methods of empowerment and responsibilities of the personnel, it also requires dividing the work into and the services provided, as well as the restructuring and integration of different activities that will undoubtedly affect or depend on the existing organizational culture. Considering the theory of the innovative company of Lazo Nick, focused on the way in which the strategy and the structure determine its competitive advantage, the companies of the service sector have shown to be important sources of innovation activities (Vila, J 2010).

The latest edition of the Oslo Manual (2006) states that its scope is about innovation in the business sector; it focuses at the company level; considers four types of innovation: product, process, organization and marketing; seeks dissemination to the level of "new for the company". 
Although the growth in the use of technology in the services and manufacturing sector for the knowledge of its processes, not all innovations are based on its use, but it is necessary that its staff be more qualified in its use, in addition of greater connection with other companies and research institutions, with a structure and culture that encourages learning and knowledge use.

It is also mentioned that a less hierarchical and flexible organization, with more autonomous jobs to make decisions and assume their responsibilities, is said to be more effective in generating radical innovations so a company can influence the efficiency of its innovation activities.

Learning is the element for personal and business improvement, through the improvement processes that prepare companies for their future. Recent studies have highlighted the need for SMEs to learn skills, have a more open culture and improve their leadership to ensure their growth (Smallborne, Leigh and North, 1995). At present there is a weak consensus about what the term culture means, how it should be measured and how it should be used for the benefit of organizations. Research indicates that explicit or implicit paradigms have been developed that influence the concepts and the global approach to their study (Barley, Meyer and Gash, 1988; Martín and Mayerson, 1988; Ott, 1989; Smircich and Calas, 1987; Van Maanen, 1988).

The first large-scale empirical study in cross-cultural management was conducted by Haire et al. (1966) where the dependent variable was the managerial attitude instead of the culture that was defined as independent and where the differences found were related to cultural differences. Subsequently, studies were developed considering culture as an independent variable (Ajiferuke and Boddewyn, 1970). Until 1972 where Triandis, defines culture as the characteristic way of a cultural group to perceive the part that man makes of their environment. And Hofstede (1980) defined it as the collective program of the mind that distinguishes the members of a human group from the members of another group.
From the constructivist approach organizations are "social constructions constituted by means of language and symbols, and constructed by interaction and a series of shared meanings. Therefore organizations not only have culture, but they are culture. In the empirical field there is a notable shortage of studies. Quantitative research indicates that there are universal elements in all cultures that can be applied to organizations, so there are common characteristics in all of them.

These use external research methods looking for several elements in different organizations. Companies can carry out innovations with objectives related to the product or service, their markets, efficiency, quality, learning capacity or the introduction of changes, but these may have internal or external obstacles such as lack of expert staff, lack of knowledge and legal or political factors. An important factor for innovation is the ability to appropriate the improvements of its activities. These companies can develop the innovations themselves or adopt them from other companies or research organizations. For this reason, it is necessary to know what is the impact that the factor of organizational culture would have on innovation for the development of small tourism businesses in the municipality of Caborca, Sonora, Mexico?

\section{Method description}

In the design of the present exploratory, descriptive quantitative research, with a nonexperimental design, the documentary technique was considered to identify if there could be a relationship between innovation as an independent variable and the independent variable of market research, in addition to the use of the bibliographic technique in the elaboration of the frame of reference and finally in the field work a structured questionnaire was used, since it is the most used in quantitative research (Corbetta, 2007).

\section{Measurement instrument design}

The "subject" based approach that addresses the innovative attitudes and activities of the company as a whole was considered. Preparing a questionnaire that was applied so that they were representative of each sector of activity such as tourism in this case and that they can be comparable internationally. (Oslo Manual, 2005).

SAUCEDO-MONARQUE, Javier， HERNÁNDEZ-PONCE， Osca Ernesto, VALDEZ-JUÁREZ, Luis Enrique. The impact of organizational culture on innovation for the development of tourism SMEs in the municipality of Caborca, Sonora. Journal of Bussines and SMEs. 2019 
The standardization of the stimulus is a fundamental characteristic of the sampling survey, which makes it possible to buy the answers and analyze them with statistical techniques (Corbetta, 2007). For this reason the questions were standardized so that all subjects were asked the same questions formulated identically.

The instrument aimed to analyze the impact of organizational culture on innovation for the development of tourism businesses in the municipality of Caborca, Sonora, Mexico, which was announced at the beginning of the questionnaire, as well as the purpose of measuring the perception that the employer and / or manager has of the relationship and impact that the aforementioned factors have.

The instrument was developed in four sections with 44 items, where the first consisted of seven items related to the general information of the interviewee and his company; the second was elaborated with five direct questions about the knowledge of innovation in tourism businesses; the third consisted of eight items related to the measurement of innovation, the next four with market research, continuing with four others concerning tourism policies, continuing with four items related to knowledge management; the penultimate section was formed of four items related to the use of technology and finally four items regarding the organizational culture); The fourth and last one consisted of four items to weigh the relationships of processes, services, organization and marketing with each of the independent variables.

\section{Measurement scale}

The role of measurement is an essential factor so that the process of observing people, objects and other subjects of the reality studied makes sense. Therefore, by means of measurement and quantification, numbers are assigned to objects or events that are taken as the unit of analysis, considering certain rules (Rositas, 2006). This process is known as the operationalization of the concepts to which values are assigned to the indicators that empirically measure the phenomenon to be studied.

For the operationalization of the variables in the design of this research, the items that support its measurement were developed.
Using the Likert scale for each of the responses of the reagents used in the measurement of the dependent and independent variables, where one (1) strongly disagrees; two (2) disagree; three (3) is Neither agree nor disagree; four (4) agrees and five (5) totally agree.

\section{Population and census}

The tourist activity is characterized by a combination of joint actions by the private initiative and the public sector and it is the tourism services companies that play an important role in the development of this activity, where, like other sectors, the small micro, medium enterprises (SMEs), form the backbone of the national economy and therefore for its impact on job creation and national production. As an analysis unit, the 120 tourism companies that the municipality of Caborca, Sonora, Mexico has been considered, according to the information provided by the management of the Office of Conventions and Visitors of the same municipality (OCV, 2016) and that of according to Manson (1993) they are in the fifth level as an organization, where they are considered as a social system with goals and instruments, plans and patterns and with different positions and roles.

Considering the population as "the totality of elements or individuals that have certain similar characteristics and on which it is desired to make inference" (Jany, 1994). A census was carried out, being surveyed in a non-probabilistic way, in this way 120 instruments were counted, which had a greater reliability in the results obtained. Of which $34.5 \%$ were hosting companies, $37.5 \%$ food and beverage companies, $15 \%$ general services, $5.4 \%$ entertainment and $.8 \%$ transportation.

\section{Instrument validation}

The validation of the instrument was carried out with experts on the subject and the pilot test of the instrument was applied to twentythree tourism entrepreneurs in the hotel and restaurant industry, through a personal interview, since they can have an overview of the companies and handle the concepts of the variables. To ensure that the results obtained have the necessary reliability and validity of the data to be collected. 
Once the surveys were applied, the data obtained were tabulated, using the SPSS program for the analysis and results of the following statisticians: the reliability analysis (Cronbach's Alpha), descriptive statistics, descriptive analysis of the sociodemographic information of the respondents, as well as knowledge of innovation in tourism businesses.

\section{Analysis of results}

An exploratory analysis was carried out where it was observed that the model did not comply with the homoscedasticity assumption, which according to Hair, Black, Babin and Anderson (2010) refers to the equality of variances between the independent variables, being able to be metric or non-metric, in relation to the independent variable, so a descriptive analysis of the variables of the model was performed, subsequently the association of the variables was analyzed by means of the chi-square model and check the predictive and explanatory power of the same through Probit and Logit analysis.

This model represents the probability that an individual chooses a certain alternative. For this reason, the value of 1 was considered for the responses in the Likert scale used from 4 to 5 and for 0 on the scale from 1 to 3 .

This model appears in the 19th century and was used by Joseph Berkson in 1944, to later be linked to the Theory of Discrete Election by McFadenn in 1973 where later the existing theory was unified to the Probit and Logit models.

The logit analysis, also called logistic regression, is an alternative to the discriminant analysis of two groups when the dependent variable is binary. The logit model calculates the probability of a binary event. Unlike the statistical regression analysis, the logit model establishes the restriction that the probability must fall between 0 and 1 .

Unlike the discriminant analysis, the logistic regression calculates the standard errors of the estimated coefficients, which allows to evaluate their significance ( Marhlote, 2010).

\section{Results}

The tabulation of the reliability results of the model is shown in Table 1. On the one hand, these results indicate that there is a relationship between the dependent variable " $Y$ " of Innovation with the independent variable: Organizational Culture. This demonstrates the reliability of the instrument, since the Cronbach alpha indices obtained are acceptable according to the standard that sets a lower limit of 0.70 and up to 0.60 in exploratory research (J. Hair, R. Anderson, R. Thatam \& W. Black, 2007). Obtaining in all variables a Cronbach Alpha above 0.80 which are acceptable.

\begin{tabular}{|l|r|r|}
\hline \multicolumn{1}{|c}{ Variable } & \multicolumn{1}{c}{$\begin{array}{c}\text { Cronbach's } \\
\text { alpha }\end{array}$} & \multicolumn{1}{c|}{$\begin{array}{c}\text { N of } \\
\text { elements }\end{array}$} \\
\hline Y= Inovation & 0.862 & 7 \\
\hline $\begin{array}{l}\text { X3= Organizational } \\
\text { Culture }\end{array}$ & 0.894 & 5 \\
\hline
\end{tabular}

Table 1 Data reliability analysis / Cronbach's Alpha Source: Self Made

The data shown in Tables 2 comes from the application of the statistical tests that show an acceptable $\mathrm{R}^{2}$ of .639 and a level of significance of .000 shown below.

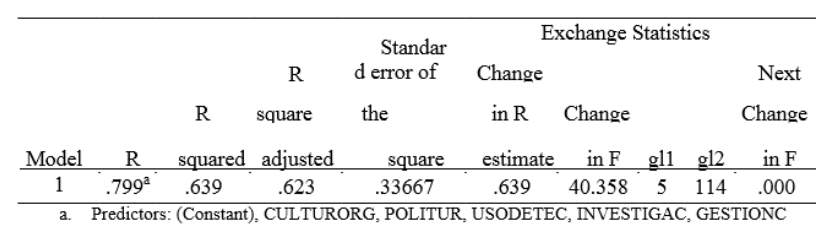

Table 2 Model Summary

Source: Self Made

In the statistical analysis, the Chi square was used to identify if there was a relationship and association between the variables of the proposed model and to justify its corresponding analysis. In the processing of the data by means of the Chi-square, two of them were eliminated since they were considered atypical, so that in total there were 118 cases analyzed. Of which the following results were obtained.

The chi-square test between the dependent variable $\mathrm{Y}=$ Innovation and the independent variable $=$ Organizational Culture obtained a p-value corresponding to $\chi^{2}=26.55$, turned out to be $<.05$ (Pearson's chi-square) with $1 \mathrm{gl}$, as shown in table 2, so it can be stated that the independent variable $=$ Organizational Culture and the dependent variable $\mathrm{Y}=$ Innovation, if they are related to each other and have a significant association of 0.000 .

SAUCEDO-MONARQUE， Javier， HERNÁNDEZ-PONCE， Oscar Ernesto, VALDEZ-JUÁREZ, Luis Enrique. The impact of organizational culture on innovation for the development of tourism SMEs in the municipality of Caborca, Sonora. Journal of Bussines and SMEs. 2019 


\begin{tabular}{|c|c|c|c|c|c|}
\hline & Value & gl & $\begin{array}{l}\text { Significance } \\
\text { asymptotic } \\
\text { (bilateral) }\end{array}$ & $\begin{array}{c}\text { Significance } \\
\text { exact } \\
\text { (bilateral) }\end{array}$ & $\begin{array}{c}\text { Significance } \\
\text { exact } \\
\text { (unilateral) }\end{array}$ \\
\hline $\begin{array}{l}\text { Pearson's } \\
\text { Chi-square }\end{array}$ & $26.550^{\mathrm{a}}$ & 1 & .000 & & \\
\hline $\begin{array}{l}\text { Continuity } \\
\text { Correction }^{\mathrm{b}}\end{array}$ & 24.685 & 1 & . 000 & & \\
\hline $\begin{array}{l}\text { Likelihood } \\
\text { ratio }\end{array}$ & 27.643 & 1 & 年. & & \\
\hline $\begin{array}{l}\text { Fisher's } \\
\text { exact test }\end{array}$ & & & & .000 & .000 \\
\hline $\begin{array}{l}\text { Linear } \\
\text { association } \\
\text { by linear }\end{array}$ & 26.325 & 1 & . 000 & & \\
\hline $\begin{array}{l}\text { N of valid } \\
\text { cases }\end{array}$ & 118 & & & & \\
\hline
\end{tabular}

Table 2 Chi-square tests - X3. Organizational culture Source: Self Made

Table 3 indicates that a Gamma coefficient of .775 was obtained indicating that there is a strong correlation between the independent variables = Organizational culture and the variable $\mathrm{Y}=$ Innovation, with an acceptable level of significance of 0.000 , as a complement to the Ji test Pearson's square made to the organizational Culture.

\begin{tabular}{|c|c|c|c|c|c|}
\hline & & Valor & $\begin{array}{l}\text { zed error } \\
\text { asymptotic } \\
\mathrm{T}\end{array}$ & & $\begin{array}{l}\text { Approximate } \\
\text { significance }\end{array}$ \\
\hline & & & approximate $^{b}$ & & \\
\hline \multirow[t]{3}{*}{$\begin{array}{l}\text { Ordinal by } \\
\text { ordinal }\end{array}$} & $\begin{array}{l}\text { Tau-b of } \\
\text { Kendall }\end{array}$ & .474 & .081 & 5.849 & .000 \\
\hline & $\begin{array}{l}\text { Tau-c of } \\
\text { Kendall }\end{array}$ & .474 & .081 & 5.849 & .000 \\
\hline & Gamma & .775 & .084 & 5.849 & .000 \\
\hline \multicolumn{2}{|c|}{$\mathrm{N}$ of valid cases } & 118 & & & \\
\hline
\end{tabular}

Table 3 Symmetric measures. Organizational culture Source: Self Made

Considering the results of the cross tables of the independent variable where the percentage of relationship that the explanatory variable (x) has with the explained variable (Y) were shown. A PROBIT analysis was performed on the independent variable, which allows the dependence of an ordinal response on an independent variable to be shaped and is used as a complement to the Logit model. This analysis can be seen in Table 5 where a higher prediction percentage of the variable $\mathrm{X}$ was obtained. Organizational culture of .454, indicating a good estimate since it is within the lower and upper limits. Having an acceptable level of significance.

\begin{tabular}{lrrrr} 
Parameter & Estimate & Next & Lower limit & $\mid$ Upper limit \\
\hline \hline X3. CULTURORG* & .454 & .000 & .219 & .689
\end{tabular}

Table 5 Probit analysis - predictive, $* 95 \%$ significance Source: Self Made

\begin{tabular}{ccccc}
\hline Parámetro & Estimación & Sig. & $\begin{array}{c}\text { Límite } \\
\text { inferior }\end{array}$ & $\begin{array}{c}\text { Límite } \\
\text { superior }\end{array}$ \\
\hline X3. CULTURORG* & .771 & .000 & .366 & 1.176 \\
\hline
\end{tabular}

Table 6 Logit analysis - explanatory, * 95\% significance Source: Self Made

\section{Conclusions}

The results obtained show the Organizational Culture variable with an important impact with the innovation-dependent variable, reflecting the link with innovation as a result of the flow of knowledge between companies and other organizations for their development and dissemination of innovations.

Learning is the element for personal and business improvement, through the improvement processes that prepare companies for their future. Recent studies have highlighted the need for SMEs to learn skills, have a more open culture and improve their leadership to ensure their growth (Smallborne, Leigh and North, 1995).

The organizational culture becomes the habits and values that order the behaviors and activities of a company (García, 2006). This variable helps us understand the way of thinking and behavior of the organization where multiple relationships converge, which allows us to know the sources of power and control exercised in their activities and that can influence for or against the innovation activities that companies tourist plans to implement.

The innovations in the organizations imply new methods of empowerment and responsibilities of the personnel, it also requires dividing the work into and the services provided, as well as the restructuring and integration of different activities that will undoubtedly affect or depend on the existing organizational culture.

Considering the theory of the innovative company of Lazo Nick, focused on the way in which the strategy and the structure determine its competitive advantage, the companies of the service sector have shown to be important sources of innovation activities (Vila, J 2010). 
The results confirm what Skarzynski, P. and Gibson, R. (2008), mention that in order to develop a strong capacity for innovation in the organization, a systematic effort of all is needed, from the support of the highest level executives, the existence of a support structure, people motivated and trained in innovation techniques, the development of monitoring and orientation processes and tools, and the strengthening of a culture and values aligned with innovation are fundamental for success.

In addition to the degree of innovation of organizations depends on exogenous variables such as the relationship of companies in the field (Lugones, G., Peirano, F., Giudicatti, M. and Raffo, J., 2003) number of commercial alliances (Freeman , 1991; Hage and Alter, 1997; Lechner, C., Dowling, M. and Welpe, I., 2006).) The link with research institutions (DeBresson and Amesse, 1991; Freeman, 1991; Hage and Alter, 1997; Lechner et al., 2006) with whom he shares knowledge (Lugones et al., 2003; González and Gálvez, 2008).

Finally, the organizational culture becomes the habits and values that order the behaviors and activities of a company (García, 2006). Organizational culture is a controllable factor that must be created from research and knowledge of the internal and external environment that through the use of technology is achieved to achieve business and tourism sector objectives, complying with policies existing tourist.

\section{References}

Abajo, E. G., \& de Santos, P. G. (2017). Medición de la competitividad turística internacional. Sesgos en la encuesta de opinión del índice de competitividad turística del Foro Económico Mundial. International journal of scientific management and tourism, 3(2), 299-322.

\section{Albornoz, W., Del Tronco, J. (2009). Políticas Públicas comparadas: Las reformas estructurales y sus resultados en América Latina. México: FLACSO-México.}

Aldebert, B., Dang, R. J., \& Longhi, C. (2011). Innovation in the tourism industry: The case of Tourism@.Tourism management, 32(5), 1204-1213.
Arzola, M., \& Mejías, A. (2007). Modelo conceptual para gestionar la innovación en las empresas del sector servicios. Revista Venezolana de Gerencia, 12(37).

Bazantes, S. G. B., Trujillo, P. E. A., \& Rivera, D. V. (2017). ESTRATEGIA DE MARKETING Y LA INNOVACIÓN EMPRESARIAL DE LA QUESERA COMUNAL PÍMBALO EN LA COMUNIDAD DE PÍMBALO, SIMIATUGGUARANDA.

Berkson, J. (1944). Application of the logistic function to bio-assay. Journal of the American Statistical Association, 39(227), 357-365.

Brida, Ramon, Such y Driha. (2016). «The Inverted-U Relationship Between the Degree of Internationalization and the Performance: The Case of Spanish Hotel Chains». Tourism Management Perspectives, vol. 17, pp. 72-81.

Camisón y Monfort. (2012) "Measuring innovation in tourism from the Schumpeterian and the dynamic-capabilities perspectives". Tourism Management 33(4): 776-789.

Carvalho, L. y Costa, T. (2011). Tourism Innovation-A Literature Review Complemented by Case Study Research. Tourism \& Management Studies, 23-33.

Čivre, y Omerzel. (2015) "The behaviour of tourism firms in the area of innovativeness". Economic Research- Ekonomska Istrazivanja 28(1): 312-330.

Corbertta, P. (2007). Metodología y Técnicas de Investigación Social, Mc Graw Hill, México, Pág. 145. COTEC, F. (2007). Las relaciones en el Sistema Español de Innovación, Libro Blanco.

Dena, J. M. M. (2019). Impacto económico del cambio climático en el cultivo del trigo en regiones productoras de Sonora, México.

Díaz, M. \& Horrillo, M. (2013). Innovación, capital intelectual y capital social territorial: enfoques clave para el éxito de la empresa turística en el nuevo entorno socio económico. Cayapa. Revista Venezolana de Economía Social, 13(25), 9-33. 
Drucker, P. F. (1985). Innovative and Entrepreneurship, Practice and Principles. New York: Harper \& Row. Retrieved April, 7, 2013.

Echevarría, J. (2008). El manual de Oslo y la innovación social. Arbor, 184(732), 609-618. Escauriaza, M. J., Subirana, J. T., \& Torres, X. T. (2001). Innovación en servicios. Cotec.

Etzkowitz, H. (2008): Innovation in action: the Triple Helix of university-industrygovernment relations". Social Science Information. Vol, 42, n. ${ }^{\text {o } 3, ~ p p . ~ 293-337 . ~}$

Fidalgo, A., Sein-Echaluce M. L., \& García F. J. (2017). Aprendizaje basado en retos en una asignatura académica universitaria. IE Comunicaciones, Revista Iberoamericana de Informática Educativa, 25, 1-8.

Formichella, M. (2005). La evolución del concepto de innovación y su relación con el desarrollo. Argentina: INTA.

Gallouj, F., Sundbo, J. (1998). Innovation in services in seven European countries. Roskilde University. Roskilde.

Gaviria, M., \& Yamid, E. (2019). Estudio de caso: aplicación del Modelo Intellectus y aproximación a la gestión del capital intelectual en una empresa industrial y comercial de la ciudad de Popayán-Cauca, en el II semestre de 2018.

Godin, B. (2008): Innovation: the History of a Category. Paper no. 1. Project on the Intellectual History of Innovation. Montreal. INRS.

González De La Fe, T. (2009). El modelo de Triple Hélice de relaciones universidad, industria y gobierno: un análisis crítico. Arbor, 185(738), 739-755.

Gössling, S. (2017). Tourism, information technologies and ustainability: an exploratory review. Journal of Sustainability Tourism, 25(7), 1024-1041.

Hair, J., Anderson, R., Taham, R., Black W. (2007). Análisis Multivariable (5a. ed.). Madrid: Prentice Hall Iberia.
Hashemkhani, S., Sedaghat, M., Maknoon, R., \& Zavadskas, E. K. (2015). Sustainable tourism: a comprehensive literature review on frameworks and applications. Economic Research-Ekonomska Istrazvanja, 28(1), 1-30.

Hjalager, A. (2012). A review of innovation research in tourism. Tourism Management, 31(1), pp1-12. Islas, M. A. A. L. T. (2019). Relación entre estilos de liderazgo y responsabilidad social empresarial en las organizaciones productoras de uva de mesa sonorense.

Jacob, Tintoré, Aguiló, Bravo y Mulet. (2003) "Innovation in the tourism sector: Results from a pilot study in the Balearic Islands". Tourism Economics 9(3): 279-295. Jany, E. (1994). Investigación integral de mercados. Bogotá: Mc Graw-Hill.

Jasso, J. (2004). Relevancia de la innovación y las redes institucionales. Red Aportes. Jiménez, J. R. R., Villalobos, J. P. D., \& Andrade, J. M. G. Cuatro décadas de Sociología en la Universidad de Sonora.

Jovicic, D. Z. (2014). Key issues in the implementation of sustainable tourism. Current Issues in Tourism, 17(4), 297-302.

Krizaj, Brodnik y Bukovec. (2014) "A tool for measurement of innovation newness and adoption in tourism firms". International Journal of Tourism Research 16: 113-125.

Lee, M. y Lan, Y. (2011). Toward a unified knowledge management model or SMEs. Expert Systems with Applications, 38(1), 729735.

León, G. (2017). Evolución de la política de I+ D e innovación en la UE. Consecuencias y oportunidades para España.

Mageswari, S. U., Sivasubramanian, C., \& Dath, T. S. (2015). Knowledge management enablers, processes and innovation in small manufacturing firms: a structural equation modeling approach. IUP Journal of Knowledge Management, 13(1), 33.

Malhorta, N. (2005). Investigación de mercados con enfoque práctico. México: Prentice-Hall. 
Martínez-Román, J. A., Tamayo, J. A., Gamero, J., \& Romero, J. E. (2015). Innovativeness and business performances in tourism SMEs. Annals of Tourism Research, 54, 118-135

McFadden, D. (1973). Conditional logit analysis of qualitative choice behavior.

Monfort, V., Camison, C. (2009). Innovación en la empresa turística. (Documento en línea). Ponencia presentada en la Primera Conferencia Internacional sobre la Medición y el Análisis Económico del Turismo Regional. Donostia.

Montoya, D. A., Carreón, F. Á., \& Ortega, A. P. P. (2018). La gestión del conocimiento y el capital intelectual en la competitividad de las SMEs manufactureras de Morelia, Michoacán. Red Internacional de Investigadores en Competitividad, 8(1).

Mowforth, M., \& Munt, I. (2015). Tourism and sustainability: Development, globalisation and new tourism in the third world. Routledge.

Nordin, S. (2003). Tourism clustering and innovation. European Tourism Research Institute.

OCDE. (2002). Frascati manual: proponed Standard practice for surveys on research and experimental development, Paris: OECD Publishing.

OCDE/ European Communites. (2006). Manual de Oslo. Guía para la recolección e interpretación de datos sobre innovación. $3^{\mathrm{a}}$. Edición. España.

OCV. (2015). Entrevista personal con Eduardo Monteverde, gerente de la Oficina de Convenciones y Visitantes del municipio de Caborca, Sonora, México.

OMT. (2013). Reporte anual de la actividad mundial del turismo. http://www2.unwto.org/es/annual- reports.

Orfila y Mattsson. (2009) "Innovation behavior in the hotel industry". Omega - The International Journal of Management Science 37: 380-394.
Peters, M. y Pikkmaat, B. (2006). Innovation in hospitality and tourism. Binghamton, NY: The Haworth Hospitality Press.

Pikkemaat y Peters. (2006) "Towards the measurement of innovation - a pilot study in the small and medium sized hotel industry". Journal of Quality Assurance in Hospitality \& Tourism 6: 89-112.

Pivcevic, y Pranicevic. (2012) "Innovation activity in the hotel sector - The case of Croatia". Ekonomska Istrazivanja 1(1): 337363.

Prats, J. O. (2008). Revisión crítica de los aportes del institucionalismo a la teoría y la práctica del desarrollo. Revista de economía institucional, 9(16).

Rastrollo, M. (2001). Resources and capabilities of tourism firms in the knowledge economy: Towards a framework in Sheldon, P., Wober, K, Fesenmaier, D. Information and Communication Technologies in Tourism. Springer Verlag, Canadá.

Romero, J. O. (2019). Percepciones de un estudio de caso sobre el Desarrollo Local. Revista Economía y Desarrollo (Impresa), 138(2).

Rositas, J. (2006). Factores críticos de éxito en la gestión de la calidad y su grado de presencia e impacto en la industria manufacturera mexicana, Monterrey, México: UANL.

Rubalcaba, L. (2015). La innovación en los servicios. 2015). La innovación y la nueva economía de servicios en América Latina y el Caribe: Retos e implicaciones de política. Montevideo: Editorial Centro de Investigaciones Económicas (CINVE, Uruguay).

Rubalcaba, L. (2015). La innovación en los servicios. En: Aboal, D.; Crespi, G. y Rubalcaba, L. (Ed.) (2015). La innovación y la nueva economía de servicios en América Latina y el Caribe: Retos e implicaciones de política. Montevideo: Editorial Centro de Investigaciones Económicas (CINVE, Uruguay). 
Sánchez, A. (2011). ¿Los principales destinos son también las principales potencias en la Investigación en turismo? Estudios turísticos, (188), 91-111.

Șchiopu, Padurean, Țala, y Nica. (2016). «The Influence of New Technologies on Tourism Consumption Behavior of the Millennials». Amfiteatru Economic, $\mathrm{n}^{\circ}$ 10; número especial.

Sorensen, G. (2007). Democracy and democratization: processes and prospects in a changing world. Hachette UK.

Volo, S. (2004). Foundation for an innovation indicator for tourism. In Keller, P., Bieger, T. (eds.). The future of small and medium sized enterprises en tourism. AIEST, St. Gallen, pp. 361-376.

WEF, F. E. M. (2016). The Global Competitiveness Report 2016-2017. World Economic Forum. 